\title{
The Influence of Work and Education and Training Disciplines on the Quality of Teacher Services at Elementary School in Ulak Baru of Cempaka District
}

\author{
Elina Kaporina $^{1 *}$, Bukman Lian², Alhadi Yan Putra ${ }^{2}$
}

\author{
${ }^{I}$ SDN Ulak Baru, South Sumatra, Indonesia \\ ${ }^{2}$ Universitas PGRI Palembang, Indonesia \\ *Corresponding author. Email: elinakaporina314@gmail.com
}

\begin{abstract}
The problem of the quality of the existing teacher services is still not optimal, it can be seen from the work done not on time. This low teacher discipline can be seen with many teachers who arrive late or do not attend the morning meeting, many teachers leave prematurely or leave the office at work hours for no apparent reason. The ability of the teachers to work is still low. There are tasks that are not in accordance with hint. Teachers' problems are often not well responded to. The training carried out is not followed seriously. Training is rarely implemented. The hypothesis in this study are 1) there is an effect of work discipline on the quality of teacher service at elementary school in Ulak Baru of Cempaka district, 2) there is an effect of education and training on the quality of teacher service at elementary school in Ulak Baru of Cempaka district, and 3) there is an influence of work discipline and education and joint training on the quality of teacher services at elementary school in Ulak Baru of Cempaka district. The data collection is done by observation, interviews and questionnaires. The analysis is carried out by the correlation analysis of the $\mathrm{t}$ test and the $\mathrm{F}$ test. The results of the data analysis from the questionnaire showed that there was an influence of work discipline on the quality of service at elementary school in Ulak Baru of Cempaka district with a t value of 6,283; the sig level was 0.000 and $\mathrm{r}$ was 0.714 . Training on the service quality of elementary school in Ulak Baru of Cempaka district with a $t$ value of 7,570, a sig 0,000 and an $r$ of 0.775 . There is an effect of work discipline and education and training together on the service quality of elementary school in Ulak Baru of Cempaka district with an F value of 29,213, a sig level of 0.000 and $r$ of 0.782 .
\end{abstract}

Keywords: Work Discipline, Education and Training, Service Quality

\section{INTRODUCTION}

Education is part of an important level in human life. The existence of human education can shape their personality by developing their potential in accordance with the values that exist in society. The values that take place are part of a process that is in line with the main goal of education, namely to develop the abilities, knowledge, skills and attitudes of students optimally. The educational process greatly determines the personality, skills and character of these humans.

Human resources in elementary school in Ulak Baru of Cempaka district need to be managed professionally in order to achieve a balance between teacher needs and demands and organizational capabilities. Especially regarding the preparation of regional budgets, it really needs personnel who are truly professional in the budget sector. This balance is the main key in order to develop productively and naturally. Human Resource Management is very important for organizations in managing, managing and utilizing teachers, so that they can function productively to achieve organizational goals, with professional human resource management, teachers are expected to work productively. The successful implementation of the duties and responsibilities of the elementary school in Ulak Baru of Cempaka district can only be achieved if it is supported by the quality of human resources who are professional, creative, disciplined, dedicated and loyal (Results of interviews with Ulak Baru elementary school teachers, Cempaka District, May 13, 2020).

Teachers as educators are one of the determining factors for the success of educational goals. Teachers who directly touch students will provide guidance that will produce the expected graduates. In the context of education, the teacher has a very large and strategic role, 
because the teacher is at the forefront of the implementation of education. It is the teacher who is face to face with students to transfer knowledge and technology while educating with positive values through guidance and exemplary [1].

The provision of public services to the public is one of the functions of government in the administration of government, especially those directly related to governance, especially those directly related to the administration of the state administration. For this reason, the manifestation of the function of the apparatus must always improve its ability in an effort to provide optimal service to the community.

To improve service to the community, the leadership of the Ulak Baru Elementary School, Cempaka District, has done various ways so that the quality of service provided by the teachers in serving the community can be carried out properly.

In this decision, it can be concluded that the philosophical basis of the above policies is to improve the ability of the state apparatus to serve, protect and foster the initiative and active role of the community in development. The main objective of this policy is to increase the usability of the government apparatus in relation to the efficient quality of service and protection to the community as well as the professional abilities of the officials. The side objective is to achieve uniformity in the basic pattern of public service management provided by government agencies to the public in various fields.

Many obstacles and limitations are encountered in creating a policy mission to increase the efficiency of government officials in providing services at the Ulak Baru Elementary School, Cempaka District. Given that until now the quality of service provided by the teachers of the Ulak Baru Elementary School, Cempaka District, has not shown maximum results where there are still obstacles and delays in serving the community, as well as limited facilities and infrastructure owned by the Ulak Baru Elementary School, Cempaka District. This is either caused by the lack of work discipline of the teachers or they do not have the ability and expertise to work.

Given the wide scope of duties and the heavy workload that must be carried out by the Ulak Baru Elementary School, Cempaka District, in this case the administration of administration must be carried out properly and demands maximum service quality from the teachers. Paying attention to the task that is carried out, the quality of service carried out by teachers of the Ulak Baru Elementary School, Cempaka District is very important in the current Regional Autonomy era. To be able to make this happen, efforts to develop the professionalism of the apparatus for teachers of the Ulak Baru Elementary School, Cempaka District, need to be continuously improved in order to increase the effectiveness of services and the quality of their services. The level of service quality of a teacher can be seen from how a teacher carries out his duties and how their ability to work. Improving the quality of teacher services means what the form, reliability and value of a person's work processes are. Professional personnel are expected to be able to build a better organization in accordance with organizational goals. In order to obtain reliable and skilled human resources, of course, a special program is needed that addresses the problems of the abilities and expertise of teachers.

To improve the quality of service for these teachers, Ulak Baru Elementary School, Cempaka District, continues to strive to improve existing management, especially human resource management. One of the factors that need improvement is teacher work discipline and providing education in the form of teacher training in work so that the quality of their services can improve. Work discipline for teachers is expected to grow from the person of a teacher himself. Thus, the teacher is aware of his duties and responsibilities as part of an organization. Even if the rules are well made, if they are not carried out with full awareness and discipline it will be useless. Because these regulations are made to be binding and must be implemented for organizational goals. The work discipline of teachers is something very important, you can imagine if a teacher does not carry out the tasks that are his responsibility, of course there will be a lot of unresolved assignments and this will have an impact on the goals and quality of his work. Work discipline is also seen to prove that a teacher is truly responsible for the organization where he works, because with high discipline the quality and quantity of the teacher's work will be very clear.

Work discipline expected of a teacher in work such as coming to the office on time and participating in all activities at the institution concerned. And what is no less important is implementing the applicable regulations, especially in the Ulak Baru Elementary School, Cempaka District. If the teacher's work discipline is low, it will certainly affect the teacher's work, and it will even be bad for the teacher concerned. Therefore, work discipline for teachers is very important in achieving organizational goals. The level of work discipline of teachers at the Ulak Baru Elementary School, Cempaka District seems to be still low, for example there are still many teachers who often don't come to work or come to work often late, as well as when many teachers go home before their time or leave the office during working hours for no apparent reason, seeing this situation work discipline is very important considering the many assignments that need to be completed and need to be completed as quickly as possible. In carrying out tasks, it requires structuring quality human resources to match the frequency of their activities. Even this arrangement and arrangement must 
be carried out effectively and efficiently. Thus, the Ulak Baru Elementary School, Cempaka District, requires attention at every level to improve the quality of the teachers' abilities so that they can work well, because this is one of the main keys.

In addition to improving the work discipline of teachers in work as stated above, the Ulak Baru Elementary School, Cempaka District, also provides education and training.

Teacher training is very much needed because with so many teachers participating in training they will automatically have high skills and abilities which will have an impact on the quality of the work of the teachers at work so that the Ulak Baru Elementary School, Cempaka District, does not need to look for honorary staff. Therefore, an important issue for an organization is how teachers have the knowledge and skills to carry out their daily duties so that they can work well and are willing to work hard to achieve maximum results. To get personnel who are truly professional in the field of protection, the Ulak Baru Elementary School, Cempaka District, continues to improve training for teachers, especially in the technical field of finance, because training is very important, especially for new teachers so that training is needed. Just like the existing teachers, they are also advised to take training so that they have increased abilities and expertise, because education and training so far have often not been followed properly and the results cannot be carried out in daily activities. Training education for teachers, especially in their field of work, namely in the financial sector, really needs to be carried out continuously so that teachers really get knowledge from the education and training that they participate in so that it can be applied in their field of work.

Training education is needed by teachers in an effort to improve their abilities and experience in carrying out their duties because if teachers are not equipped with certain training, they may experience obstacles in completing their tasks, especially those related to information technology. Training is not only expected so that teachers have skills, knowledge and expertise, but so that teachers can create apparatus capable of acting as reformers and gluing together unity and integrity and creating a common vision and dynamic mindset in carrying out general government and development tasks for the realization of a good governance.

According to Article 31 paragraph (1) of Law Number 43 of 1999 , in order to achieve maximum effectiveness and efficiency, the regulation and implementation of education and training for civil servant positions is aimed at improving service, quality, expertise, ability and skills. Competence that is truly reliable will make civil servants able to compete, anticipate and innovate in carrying out their job duties.
This ability can be obtained by providing opportunities for teachers to go through education and training. Thus, formal education becomes the basis of competence, while education and training support competence.

By paying attention to the above background, the authors are interested in examining the effect of work discipline and education and training on the quality of teacher service at Ulak Baru Elementary School, Cempaka District.

\section{METHODS}

The research was conducted at Ulak Baru Elementary School. In this study the authors used quantitative data, namely research that is required to use numbers, starting from data collection, interpretation of the data, and the appearance of the results. Quantitative research is a type of research whose specifications are systematic, planned, and clearly structured from the start to the making of the research design.

According to [8] Population is "a generalization area consisting of objects or subjects that have certain quantities and characteristics that are expected by researchers to study and then draw conclusions". The population in this study were all elementary school teachers in Ulak Baru which consisted of 3 elementary schools, namely elementary school 1 Ulak Baru. 14 teachers, elementary school 01 Gunung Jati 13 teachers, elementary school 02 Gunung Jati 13 teachers with a total of 40 teachers.

The sample is part or representative of the population under study [9]. To determine the size of the sample if the subject is less than 100 , it is better to take all of them so that the research is population research. If the subject is bigger it can be taken between $20-25 \%$ [9].

In this study, all of the population was taken as the research sample, namely 40 people, while 20 people were used to test research instruments taken from other schools.

The types of data needed in this study are primary data and secondary data. The primary data source comes from empirical research results through distributing questionnaires to the Ulak Baru Elementary School, Cempaka District as respondents. Meanwhile, secondary data is obtained from annual reports, teacher data, and office documentation.

\section{RESULTS AND DISCUSSION}

This hypothesis testing is done by using correlation techniques, while the correlation techniques used are statistical analysis of correlation and determination, regression coefficient ( $t$ test) and association correlation 
coefficient ( $\mathrm{F}$ test), which were carried out using SPSS version 21 .

\section{Hypothesis Testing of Work Discipline (X1) on Performance ( $Y$ )}

From the Table 1 , the $\mathrm{t}$ value is 6,283 with a sig level of 0,000 . Because the sig value is less than 0.05 , the hypothesis which says there is an effect of work discipline on teacher performance at Ulak Baru Elementary School, Cempaka District is accepted.

Table 1 X1 Against Y

\begin{tabular}{|c|c|c|c|c|c|c|}
\hline \multicolumn{7}{|c|}{ Coefficients $^{a}$} \\
\hline & & \multicolumn{2}{|c|}{$\begin{array}{l}\text { Unstandardized } \\
\text { Coefficients }\end{array}$} & \multirow{2}{*}{\begin{tabular}{|c|}
$\begin{array}{c}\text { Standardized } \\
\text { Coefficients }\end{array}$ \\
Beta \\
\end{tabular}} & \multirow[b]{2}{*}{$\mathrm{t}$} & \multirow[b]{2}{*}{ Sig. } \\
\hline \multicolumn{2}{|c|}{ Model } & $\mathrm{B}$ & Std. Error & & & \\
\hline \multirow[t]{2}{*}{1} & (Constant) & 1.998 & 10.284 & & .194 & .847 \\
\hline & $\begin{array}{l}\text { Disiplin } \\
\text { kerja }\end{array}$ & .792 & .126 & .714 & 6.283 & .000 \\
\hline
\end{tabular}

2. Hypothesis Testing on Education and Training (X2) on Performance (Y).

From the Table 2, the $\mathrm{t}$ value is 7.570 with a sig level of 0.000 . Because the sig value is less than 0.05, the hypothesis that there is an effect of education and training on teacher performance at Ulak Baru Elementary School, Cempaka District is accepted. This means that education and training affect the performance of teachers at the Ulak Baru Elementary School, Cempaka District.

Table 2 X2 Against Y

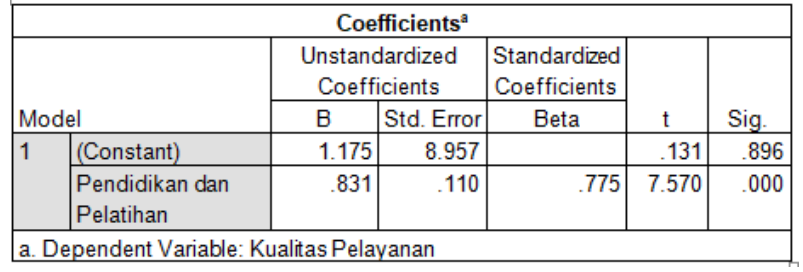

\section{Hypothesis Testing of Work Discipline (X1) and Education and Training (X2) on Performance (Y)}

From the Table 3 , the $\mathrm{F}$ value is 29,213 with a sig level of 0,000 . Because the sig value is less than 0.05 , the hypothesis which says there is an influence of work discipline and education and training on the quality of service at the Ulak Baru Elementary School, Cempaka District is accepted.
Table 3 X1 and X2 Against Y

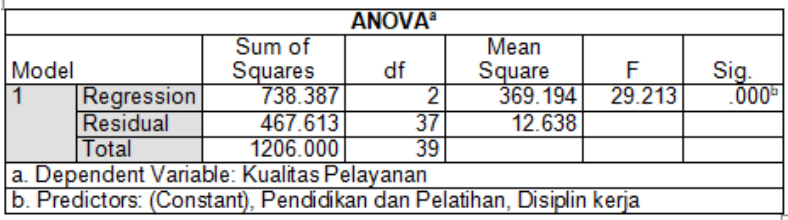

\section{CONCLUSION}

Based on the results of research and discussion that has been done before, either through descriptive statistical analysis or inferential statistical analysis, the findings in this study can be concluded as follows: There is an effect of work discipline on the quality of service at the Ulak Baru Elementary School, Cempaka District. There is an effect of Education and Training on the quality of services at the Ulak Baru Elementary School, Cempaka District. There is an influence of work discipline and education and training together on the quality of service at the Ulak Baru Elementary School, Cempaka District.

For researchers to follow up further on the results of this study by developing independent variables that can improve the performance of the Ulak Baru Elementary School, Cempaka District. This needs to be done because there are still other factors that have an influence on service quality besides work discipline and education and training because only $61.2 \%$ of the service quality is determined by work discipline and education and training meaning $38.8 \%$ is determined by factors outside work discipline and education training such as compensation, job satisfaction and others.

\section{REFERENCES}

[1] e-Jurnal, Pengaruh Pelatihan Dan Motivasi Kerja Terhadap Kinerja Mengajar Guru IPA Di SMP SeKota Poso. Mitra Sains, 5(2), 58-66.

[2] Tjiptono, F. (2008). Service Management, Edisi kedua. Yogyakarta: Andi Ofset.

[3] Moekijat. (2012). Manajemen Kepegawaian. Bandung, Mandar Maju

[4] Netisemito. (2002). Manajemen Personalia, Ghalia Indonesia. Jakarta.

[5] Simamora, H. (2017). Manajemen Sumber Daya Manusia. Yogyakarta: STIE YKPN.

[6] Suradinata. (2017). Peranan Kepemimpinan dalam Motivasi Kerja. Bandung: Ramadhan.

[7] Soekidjo, N. (2012). Analisis serta Perumusan Kebiajkan dan Strategi Organisasi. Jakarta: Gunung Agung.

[8] Sugiyono. (2017). Penelitian Sosial Jakarta: Gramedia Pustaka Utama. 
[9] Arikunto, S. (2013). Metode Penelitian dan Statistika. Dunia Pustaka Jaya. Jakarta.

[10] Kusumaningrum, D. E., Sumarsono, R. B., \& Gunawan, I. (2019). Professional Ethics And Teacher Teaching Performance: Measurement Of Teacher Empowerment With A Soft System Methodology Approach. International Journal Of Innovation, Creativity And Change, 5(4), 611-624.

[11] Pertiwi, A. K., Cahyani, S. S. A., Diana, R. C., \& Gunawan, I. (2018, October). The Leadership Of Kyai: A Descriptive Study. In 3rd International Conference On Educational Management And Administration (Coema 2018). Atlantis Press.

[12] Nurabadi, A., Sucipto, S., Juharyanto, J., \& Gunawan, I. (2018, October). The Implementation Of Education Management Standards In The School Laboratory State University Of Malang For Improving Educational Quality. In 3rd International Conference On Educational Management And Administration (Coema 2018). Atlantis Press.
[13] Hardika, H., Aisyah, E. N., \& Gunawan, I. (2018, October). Facilitative Learning To Improve Student Learning Creativity. In 3rd International Conference On Educational Management And Administration (Coema 2018). Atlantis Press.

[14] Agustina, N. E., Sumarsono, R. B., \& Gunawan, I. (2018, September). Implementation Of School And Community Relationship Techniques (A Case Study In SDN Karangbesuki 2 Malang, Indonesia). In 1st International Conference On Early Childhood And Primary Education (ECPE 2018). Atlantis Press.

[15] Bafadal, I., Nurabadi, A., \& Gunawan, I. (2018, December). The Influence Of Instructional Leadership, Change Leadership, And Spiritual Leadership Applied At Schools To Teachers' Performance Quality. In International Conference On Education And Technology (ICET 2018). Atlantis Press. 